\title{
Natural Variation in Virulence of Acidovorax citrulli Isolates That Cause Bacterial Fruit Blotch in Watermelon, Depending on Infection Routes
}

\author{
Yu-Rim Song, In Sun Hwang, and Chang-Sik Oh (iD) * \\ Department of Horticultural Biotechnology, College of Life Sciences, Kyung Hee University, Yongin 17104, Korea
}

(Received on October 3, 2019; Revised on November 13, 2019; Accepted on December 2, 2019)

Acidovorax citrulli causes bacterial fruit blotch in $\mathrm{Cu}$ curbitaceae, including watermelon. Although $A$. citrulli is a seed-borne pathogen, it can cause diverse symptoms in other plant organs like leaves, stems and fruits. To determine the infection routes of $A$. citrulli, we examined the virulence of six isolates (Ac0, Ac1, Ac2, Ac4, Ac8, and Ac11) on watermelon using several inoculation methods. Among six isolates, DNA polymorphism reveals that three isolates Ac0, Ac1, and Ac4 belong to Clonal Complex (CC) group II and the others do CC group I. Ac0, Ac4, and Ac8 isolates efficiently infected seeds during germination in soil, and Ac0 and Ac4 also infected the roots of watermelon seedlings wounded prior to inoculation. Infection through leaves was successful only by three isolates belonging to $\mathrm{CC}$ group II, and two of these also infected the mature watermelon fruits. Ac2 did not cause the disease in all assays. Interestingly, three putative type III effectors (Aave_2166, Aave_2708, and Aave_3062) with intact forms were only found in CC group II. Overall, our results indicate that $A$. citrulli can infect watermelons through diverse routes, and the $\mathrm{CC}$ grouping of $A$. citrulli was only correlated with virulence in leaf infection assays.

Keywords : bacterial fruit blotch, clonal complex groups, effector genes, infection, virulence

\footnotetext{
*Corresponding author.

Phone) +82-31-201-2678, FAX) +82-31-204-8116

E-mail)co35@khu.ac.kr

ORCID

Chang-Sik Oh

https://orcid.org/0000-0002-2123-862X

(c) This is an Open Access article distributed under the terms of the Creative Commons Attribution Non-Commercial License (http:// creativecommons.org/licenses/by-nc/4.0) which permits unrestricted noncommercial use, distribution, and reproduction in any medium, provided the original work is properly cited.
}

Articles can be freely viewed online at www.ppjonline.org.
Handling Editor : Sang-Wook Han

Bacterial fruit blotch (BFB) is caused by the Gram-negative bacterium Acidovorax citrulli (previously known as Acidovorax avenae subsp. citrulli) in Cucurbitaceae, including watermelon (Citrullus lanatus) and melon (Cucumis melo) (Schaad et al., 1978, 2008; Willems et al., 1992). The disease was first reported in Georgia, USA in 1965 (Webb and Goth, 1965), and has been reported worldwide (Burdman and Walcott, 2012). The typical symptoms caused by $A$. citrulli are water-soaking regions in cotyledons and leaves followed by necrotic symptoms, wilting and necrosis on stems, and irregularly-shaped water-soaked lesions on fruits (Schaad et al., 2003).

A. citrulli isolates have been divided into two groups. Group I is moderately aggressive on all cucurbit host plants except watermelon, while group II causes more severe symptoms on watermelon than on other host plants (Walcott et al., 2004). These groups coincide with the Clonal Complex (CC) groups I and II, based on multi-locus sequence typing analysis (Feng et al., 2009). In addition, CC groups can be easily distinguished by DNA sequence polymorphisms in the housekeeping gene gltA: the isolates in $\mathrm{CC}$ group I have $\mathrm{C}, \mathrm{G}$, and $\mathrm{A}$, while the isolates in $\mathrm{CC}$ group II have $\mathrm{G}, \mathrm{A}$, and $\mathrm{C}$ at the positions 439, 442, and 451 from the start codon, respectively (Song et al., 2015; Yan et al., 2013).

A. citrulli is known as a seed-borne pathogen, and infected seeds have been considered as the primary inoculum for BFB epidemics (Hopkins and Thompson, 2002; Latin and Hopkins, 1995; Rane and Latin, 1992). One of the known infection routes of A. citrulli into seeds is through a pollinated female flower (Walcott et al., 2003). Particularly, pathogen infection through the pistil causes deep infection into the cotyledon part of the mature seed, resulting in longer bacterial survival in seeds (Block and Shepherd, 2008; 
Dutta et al., 2012). The cotyledons grown from infected seeds may be the main source for a secondary inoculum for spreading $A$. citrulli to neighboring healthy seedlings (Chalupowicz et al., 2015). Thus, seed decontamination is an important strategy for BFB management (Kubota et al., 2012).

Because BFB symptoms occur on a range of plant organs such as leaves and fruits of watermelon, A. citrulli must have the ability to infect host plants through other organs besides flowers. Previous reports showed that $A$. citrulli could infect melon leaves after spray inoculation and moved to stems (Alves et al., 2010; Neto et al., 2006). A. citrulli was also able to colonize and move through xylem vessels to probably reach fruits and seeds (Bahar et al., 2009). Moreover, this pathogen passively moved to soil after irrigation from infected cotyledons of melon seedlings to roots of neighboring seedlings, and eventually migrated to stems in the neighboring hosts (Chalupowicz et al., 2015). However, a detailed dissection of infection routes and their relationship with virulence of $A$. citrulli in host plants still remains to be determined.

Thus, in this study, we hypothesized that $A$. citrulli could infect host plants through diverse routes and so focused on investigating possible routes of $A$. citrulli infection other than flowers in watermelon. In addition, we examined if $\mathrm{CC}$ grouping is related with infection routes and virulence of $A$. citrulli isolates.

\section{Materials and Methods}

Bacterial isolates and inoculum preparation. Six $A$. citrulli isolates isolated from watermelon showing disease symptom (Ac0, Ac2, Ac4, Ac8, and Ac11 isolates) or its root stock (Ac1 isolate) were used in this study (RahimiMidani et al., 2018) (Table 1). One was obtained from Koran Agricultural Culture Collection (KACC17005;
Ac0) and five from Nongwoo Bio Co. (Suwon, Korea; Ac1, Ac2, Ac4, Ac8, and Ac11). Each isolate was confirmed by PCR with the species-specific primers SEQID4 (5'-TCGTCATTACTGAATTTCAACA-3') and SEQID5 (5'-CCTCCACCAACCAATACGCT-3') amplifying the 16/25S rRNA gene region (Makizumi et al., 2011; Schaad et al., 2000). For monitoring A. citrulli populations in watermelon after inoculation, a rifampicin-resistant strain of each isolate was generated as previously described (Choi et al., 2016) and used for plant assays. A. citrulli isolates and strains were stored at $-80^{\circ} \mathrm{C}$ with $25 \%$ glycerol and cultured at $26^{\circ} \mathrm{C}$ on King's B medium (containing proteose peptone $20 \mathrm{~g}, \mathrm{~K}_{2} \mathrm{HPO}_{4} 1.5 \mathrm{~g}, \mathrm{MgSO}_{4} 1.5 \mathrm{~g}$, glycerol $10 \mathrm{ml}$, agar $15 \mathrm{~g}$ in 1,000 ml distilled water) with $50 \mathrm{mg} / 1$ rifampicin.

To prepare inoculum for plant assays, rifampicin-resistant $A$. citrulli strains were pre-cultured in $5 \mathrm{ml}$ of King's B broth in a $14 \mathrm{ml}$ round bottom culture tube (SPL Life Sciences Co., Ltd., Pocheon, Korea) at $26^{\circ} \mathrm{C}$ overnight in a shaking incubator at $180 \mathrm{rpm}$. One hundred microliters of overnight cultures were used to re-culture them in 20 $\mathrm{ml}$ of King's B broth in a $50 \mathrm{ml}$ snap tube (SPL Life Sciences Co., Ltd.) overnight. After centrifugation of bacterial culture at 8,000 rpm for $3 \mathrm{~min}$, the pellet was washed with $20 \mathrm{ml}$ of $10 \mathrm{mM} \mathrm{MgCl}_{2}$. After washing once, the pellet was re-suspended with the same buffer and diluted to $10^{6} \mathrm{cfu} / \mathrm{ml}$ as an inoculum.

Detection of $A$. citrulli by PCR. The PCR method with SEQID4F and SEQID5R primer set was used to detect $A$. citrulli isolates from watermelon seeds, leaves, seedlings, or plants. PCR amplification was conducted in a $10 \mu \mathrm{l}$ reaction with $2 \times$ pre-mixed Taq (Enzynomics, Daejeon, Korea) and $1 \mu \mathrm{l}$ of plant extracts, according to the manufacturer's instructions. The PCR cycle was as follows: $95^{\circ} \mathrm{C}$ for $5 \mathrm{~min}$ followed by 30 cycles of PCR consisting of denaturation

Table 1. Acidovorax citrulli isolates used in this study

\begin{tabular}{|c|c|c|c|c|c|c|}
\hline Isolates & Strain names ${ }^{\mathrm{a}}$ & Isolation sites & Isolated hosts & $\begin{array}{c}\text { DNA polymorphism }^{\text {b }} \\
(439,442,451)\end{array}$ & $\begin{array}{l}\text { Clonal } \\
\text { complex }^{\mathrm{c}}\end{array}$ & Sources \\
\hline $\mathrm{Ac0}$ & KACC17005 & Suwon, South Korea & Watermelon & $\mathrm{G}, \mathrm{A}, \mathrm{C}$ & II & KACC \\
\hline Acl & NWBSC074 & Gimje, South Korea & Watermelon rootstock & $\mathrm{G}, \mathrm{A}, \mathrm{C}$ & II & Nongwoo Bio Co. \\
\hline Ac2 & NWBSC107 & Haman, South Korea & Watermelon & $\mathrm{C}, \mathrm{G}, \mathrm{A}$ & I & Nongwoo Bio Co. \\
\hline Ac4 & NWBSC109 & Buyeo, South Korea & Watermelon & $\mathrm{G}, \mathrm{A}, \mathrm{C}$ & II & Nongwoo Bio Co. \\
\hline Ac8 & NWBSC196 & Miryang, South Korea & Watermelon & $\mathrm{C}, \mathrm{G}, \mathrm{A}$ & I & Nongwoo Bio Co. \\
\hline Ac11 & NWBSC206 & Nonsan, South Korea & Watermelon & $\mathrm{C}, \mathrm{G}, \mathrm{A}$ & I & Nongwoo Bio Co. \\
\hline
\end{tabular}

${ }^{a}$ Names, originated from Park et al. (2017) and Rahimi-Midani et al. (2018).

${ }^{b}$ DNA polymorphism at the indicated base pair position from the start codon of gltA gene.

${ }^{\mathrm{c}}$ Based on DNA polymorphism in the housekeeping gene gltA (Song et al., 2015; Yan et al., 2013). 
at $95^{\circ} \mathrm{C}$ for $1 \mathrm{~min}$, annealing at $55^{\circ} \mathrm{C}$ for $30 \mathrm{~s}$, and extension at $72^{\circ} \mathrm{C}$ for $30 \mathrm{~s}$. Five microlters of PCR products was separated by electrophoresis at $135 \mathrm{~V}$ for $15 \mathrm{~min}$ on a $1.5 \%$ agarose gel in $0.5 \times$ TBE buffer with a $1 \mathrm{~kb}$ DNA ladder (Sigma-Aldrich, St. Louis, MO, USA).

Inoculation of $A$. citrulli by soil mixing. Soil contaminated with this bacterium was produced by pouring $50 \mathrm{ml}$ of each bacterial isolate into $165 \mathrm{~g}$ of sterile soil $\left(3 \times 10^{5}\right.$ $\mathrm{cfu} / \mathrm{g}$ ). Right after, five seeds of watermelon cultivar 'Speed Plus' (Nongwoo Bio Co.), which was commercially available, were sown in this soil in each hole of a 32-hole tray (Seoul Bio, Eumseong, Korea), and 20 seeds were used for each isolate. The tray was kept in an incubator at $26^{\circ} \mathrm{C}$, and symptom development in the seedlings was monitored for 2 weeks. The severity of disease symptom in the seedlings was scored based on the following disease indices: 0 , no symptom; 1, weak water-soaking spots on cotyledon; 2 , strong water-soaking or necrosis spots on cotyledon; 3 , stem bending; 4, stem falling; 5, whole plant death (Supplementary Fig. 1A). To measure the bacterial titer in the seedling, the hypocotyls from 4 seedlings was ground after surface sterilization with $1 \%$ sodium hypochlorite for $30 \mathrm{~s}$ and washing twice with distilled water. Then, the extracts were re-suspended with $500 \mu \mathrm{l}$ of $10 \mathrm{mM} \mathrm{MgCl}_{2}$ and serially diluted. The extracts were placed on King's B (KB) agar plate with $50 \mu \mathrm{g} / \mathrm{ml}$ rifampicin for growth of bacterial colonies. These experiments were repeated twice with the similar results.

Inoculation of $A$. citrulli by soil drenching. Five-dayold seedlings were treated with $10^{6} \mathrm{cfu} / \mathrm{ml}$ of bacterial suspension by pouring it near seedlings in a pot, and six seedlings were used per each isolate. To check if wounding in roots can increase infection by $A$. citrulli, the 5-day-old watermelon seedlings were pulled out, and their roots were cut by scissors. After they were re-planted, each bacterial suspension $\left(10^{6} \mathrm{cfu} / \mathrm{ml}\right)$ or $10 \mathrm{mM} \mathrm{MgCl}{ }_{2}$ as a mock treatment was poured into soil near the seedlings. Six seedlings were used per each isolate. Then, symptom development was observed for one week, and the disease severity in the seedlings was scored, as described above (Supplementary Fig. 1A). These experiments were repeated twice with the similar results.

Spray inoculation of $A$. citrulli. Three-week-old watermelon plants were sprayed with $10 \mathrm{mM} \mathrm{MgCl} 2$ or bacterial suspension with $0.02 \%$ silwet to make them completely wet, and 8 to 12 seedlings per each isolate were used. The treated plants were covered with clear vinyl for $24 \mathrm{~h}$ to retain humidity. On the seventh day after spray inoculation (dai), a bacterial titer in leaves was measured after surface sterilization. The disease severity in the leaves was scored based on based on the following disease indices: 0 , no symptom; 1, yellowing and marginal necrosis; 2, complete necrosis (Supplementary Fig. 1B). These experiments were repeated twice with the similar results.

Syringe or vacuum infiltration of $A$. citrulli. For syringe infiltration, five fully developed leaves of 3-week-old watermelon seedlings per treatment were infiltrated with 10 $\mathrm{mM} \mathrm{MgCl}{ }_{2}$ or bacterial suspension $\left(10^{4} \mathrm{cfu} / \mathrm{ml}\right)$ using a needleless syringe. For vacuum infiltration, the aerial parts of 3-week-old seedlings were dipped into each $A$. citrulli culture suspension $\left(10^{6} \mathrm{cfu} / \mathrm{ml}\right)$ in the vacuum infiltration system (Rocker410, SPARMAX, Taipei, Taiwan) with the vacuum pump on to let bacterial cells enter into the leaves. In both cases, development of disease symptoms in leaves was monitored for 2 weeks, and, to measure a bacterial titer in the infiltrated leaves, four leaf discs per treatment were collected with a 6-mm diameter cork-borer every 2 dai. The disease severity in the leaves was scored based on disease index scale in Supplementary Fig. 1B.

Inoculation of $A$. citrulli by fruit injection. For fruit inoculation, the surface of mature harvested watermelon fruits was punctured with a $200 \mu \mathrm{l}$ pipette tip at a depth of $2.5 \mathrm{~cm}$, and $50 \mu \mathrm{l}$ of bacterial suspension $\left(10^{6} \mathrm{cfu} / \mathrm{ml}\right)$ per each isolate was injected inside the puncture. Development of disease symptom was monitored for 2 to 3 weeks. Then, the fruits were cut and symptoms inside the fruits were observed. To determine if $A$. citrulli could enter into seeds, all seeds from watermelon fruit injected with Ac1 isolate, which caused the most severe symptom in fruit, were harvested 10 and 40 dai. After surface sterilization of seeds, each seed was ground separately with $500 \mu \mathrm{l}$ of 10 $\mathrm{mM} \mathrm{MgCl}$ buffer. After 30 min shaking, the extracts were diluted 10 times and then placed on KB medium for colony development. These experiments were repeated twice with the similar results.

Effector gene prediction and profiling. Prediction of open reading frames (ORFs) of putative effecter genes was performed by Artemis v.17.0.1 (http://www.sanger.ac.uk/ science/tools/artemis). To check the intact putative effector genes in A. citrulli isolates, the genome sequence was used for Ac0 isolate (Park et al., 2017), and gene-specific primers (Supplementary Table 1) were designed, and PCR with those primers was performed for other five isolates. The PCR products were purified and sequenced. 
Statistical analysis. For bacterial titers, Duncan's multiple range test $(P<0.05)$ was performed with SAS (version 9.4 for Windows; SAS Institute Inc., Cary, NC, USA). For disease severity, non-parametric statistics were performed by Kruskal-Wallis test using statistiXL (v. 1.8, 2008, statistiXL-Nedlands, WA, Australia, http://www.statistiXL. com).

\section{Results}

Grouping and preparation of rifampicin-resistant $A$. citrulli isolates. Six A. citrulli natural isolates isolated from watermelon showing disease symptoms or watermelon root stock from different locations in South Korea were obtained (Table 1). By checking DNA sequences of the gltA housekeeping gene in these six isolates, they were divided into two groups: Ac2, Ac8, and Ac11 in CC group I and Ac0, Ac1, and Ac4 in CC group II (Table 1). To distinguish $A$. citrulli isolates used in this study from other bacteria, their spontaneous mutants resistant to rifampicin antibiotics were generated and used for further experiments.

Infection efficiency and virulence of six $A$. citrulli isolates from soil to watermelon seeds. To examine if $A$. citrulli can infect watermelon seeds during germination in soil, soil was infested with $3 \times 10^{5} \mathrm{cfu} / \mathrm{g}$ of each iso-
A

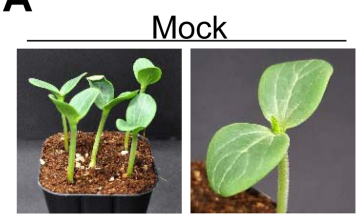

Ac1

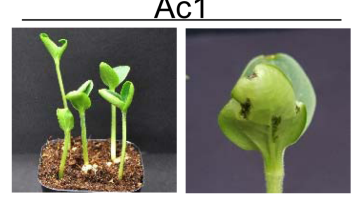

Ac4

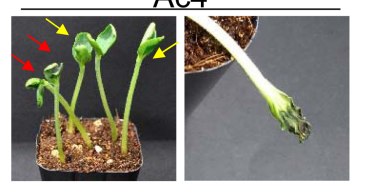

Ac11

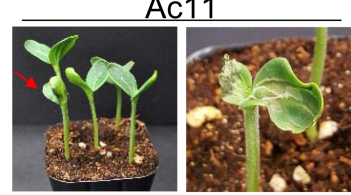

C
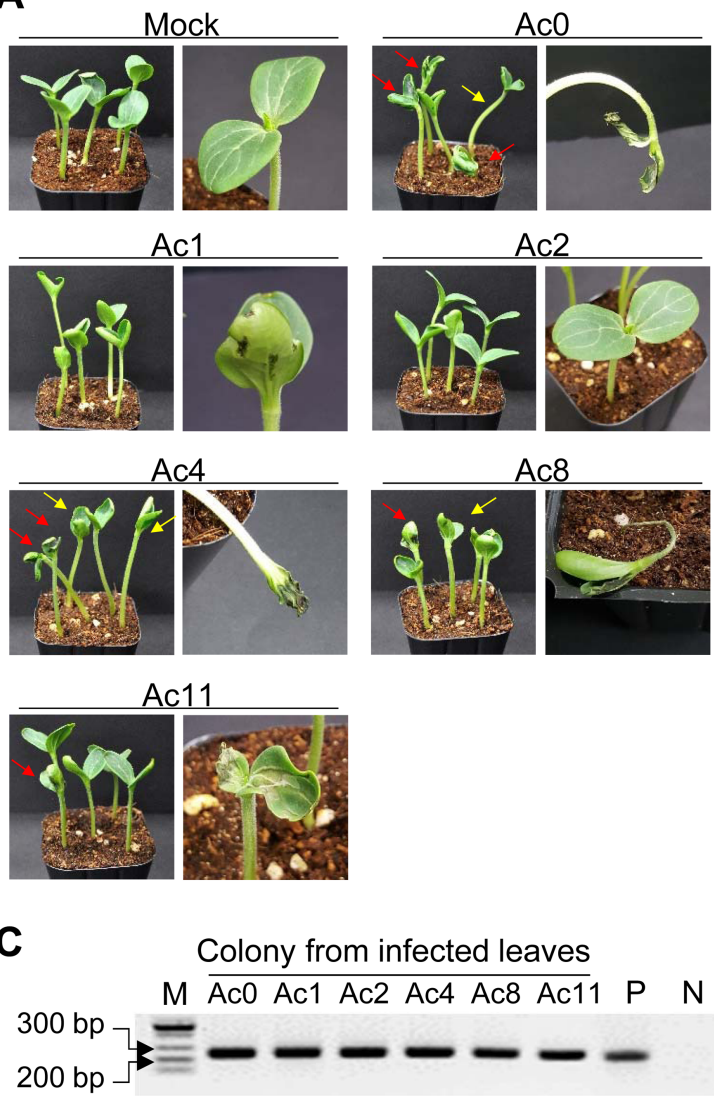

Ac2

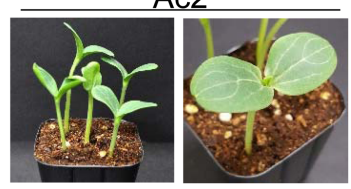

Ac8
B

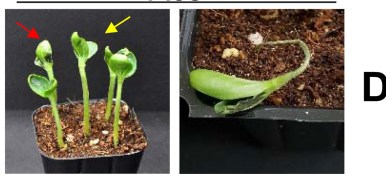

.

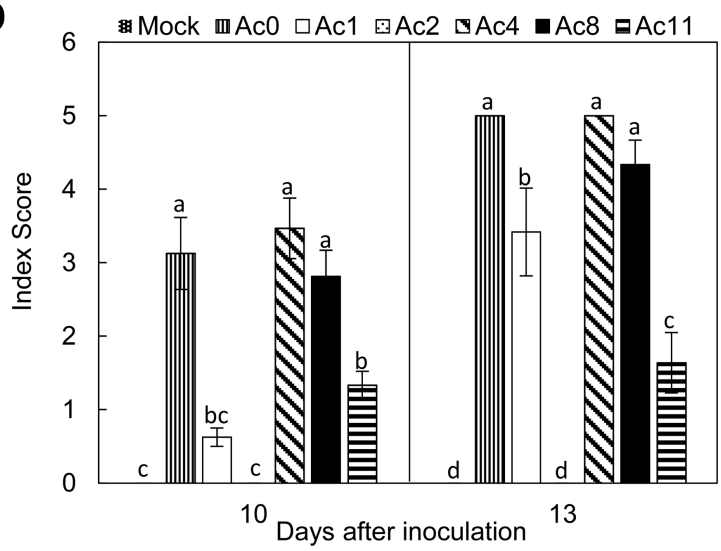

Fig. 1. Infection efficiency and virulence of six Acidovorax citrulli isolates through soil. (A) The seeds were sowed in soil infested with $10^{6} \mathrm{cfu} / \mathrm{ml}$ of each indicated isolate. $10 \mathrm{mM} \mathrm{MgCl}_{2}$ buffer was used as a mock control. Watermelon seedlings showing typical symptoms, water-soaked spots, blotch or wilting, at 7 days after inoculation (dai). The red and yellow arrows in left pictures indicate severe blotch and weak symptom, respectively. Right pictures are representatives of seedlings showing the most severe symptoms. (B) The disease severity by bacterial isolates at 10 dai and 13 dai that was scored according to the following disease index scale: 0 , no symptoms; 1 , slight water-soaking spots on cotyledon; 2, massive water-soaking or necrosis spots on cotyledon; 3, bending of stem; 4, falling stem; 5, necrosis of whole plant (Supplementary Fig. 1A). Bars represent standard error $(n=20)$. (C) Confirmation of the presence of inoculated bacteria by PCR. The colonies isolated from infiltrated leaves were confirmed by PCR using the 16/25S rRNA gene primer set. M, $1 \mathrm{~kb}$ ladder marker; P, Ac0 genomic DNA (positive control); $\mathrm{N}, \mathrm{H}_{2} \mathrm{O}$ (negative control). (D) Bacterial cell numbers in watermelon seedlings at 7 dai and 10 dai. Y-axis represents mean $\log _{10} \mathrm{cfu} / \mathrm{g}$ of watermelon, and bars indicate standard error $(n=4)$. The letters on top of error bars show results from Duncan's multiple range test $(P<0.05)$. 
late, and then watermelon seeds were sowed. First, the germination rate was almost over $90 \%$ for all treatments. Second, symptom development and disease severity were monitored for 2 weeks. Common symptoms in the young seedlings were water-soaking at the cotyledons, later turning to leaf necrosis and eventually wilting and necrosis of the whole seedlings (Fig. 1A). These symptoms were observed in seedlings grown in soil infested with all isolates except Ac2 (Fig. 1A). Disease severity caused by six isolates showed similar patterns in 10 and 13 dai (Fig. 1B). Disease severity was the highest and similar in Ac0, Ac4, and Ac8, followed by Ac1 and Ac11. The Ac2 isolate consistently failed to cause obvious disease symptom even two weeks after inoculation. Third, bacterial titers per gram of seedlings were measured at 7 and 10 dai. Before measuring the titers, the bacteria isolated and grown on medium with rifampicin were confirmed by PCR (Fig. 1C). Consistent with disease severity, $\mathrm{Ac} 0, \mathrm{Ac} 4$, and $\mathrm{Ac} 8$ isolates showed
A
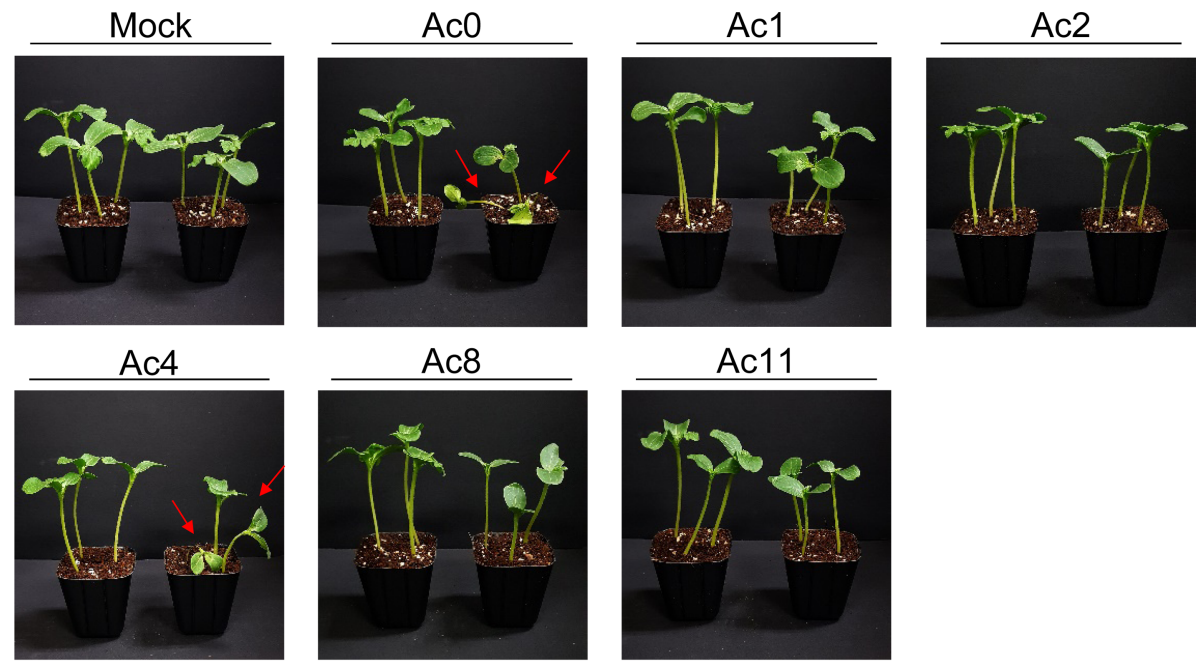

B

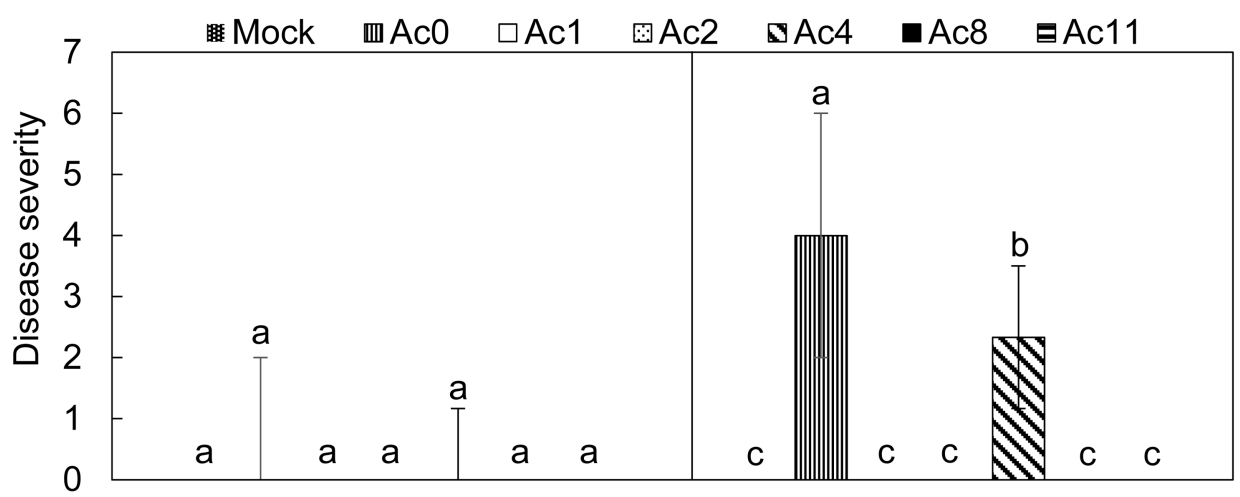

C

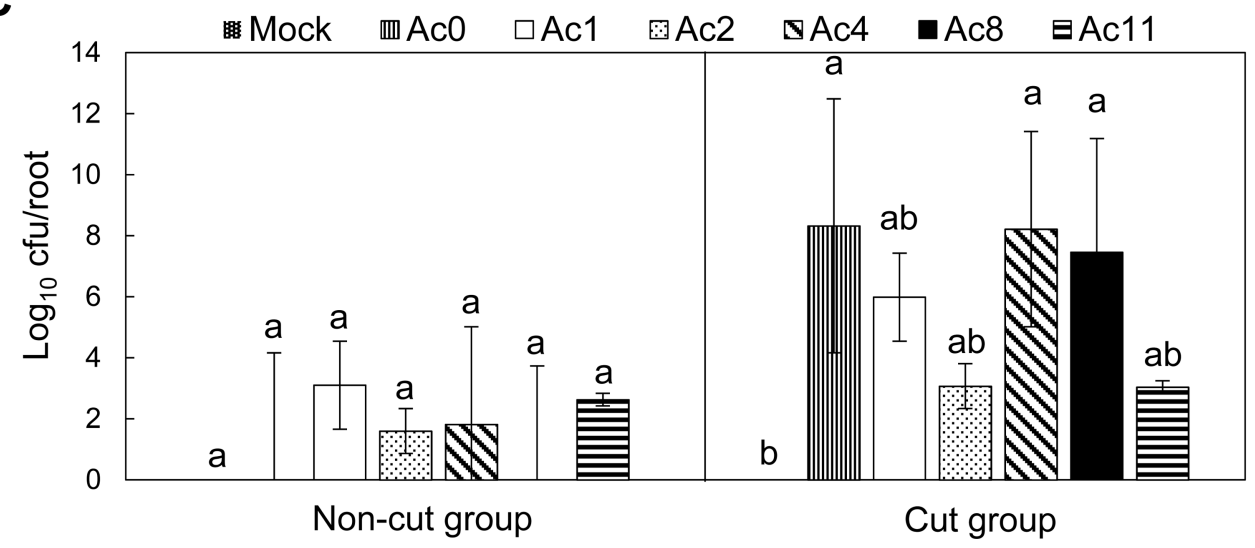

Fig. 2. Infection efficiency and virulence of six Acidovorax citrulli isolates through wounding in roots. The watermelon seedlings were pulled out to injure the roots on the fifth day after sowing and their roots were cut by scissors. After they were re-planted, each bacterial suspension $\left(10^{6} \mathrm{cfu} / \mathrm{ml}\right)$ or $10 \mathrm{mM}$ $\mathrm{MgCl}_{2}$ as a mock treatment was poured into soil near seedlings. (A) Watermelon seedlings showing symptoms at 2 days after inoculation (dai). In photos, left and right pots represent non-cut and cut groups, respectively. The arrows indicate symptomatic watermelon. (B) The disease severity by bacterial isolates at 2 dai that was scored according to disease index scale in Supplementary Fig. 1A. Bars represent standard error $(n=6)$. (C) The bacterial concentration in noncut- or cut- roots of watermelon seedlings at 2 dai. Y-axis indicate the average of bacterial cell numbers per seedling $\left(\log _{10} \mathrm{cfu} /\right.$ root). Bars represent standard error $(n=3)$ and the letters on top of error bars show results from Duncan's multiple range test $(P$ $<0.05)$. 
high titers compared with other isolates at 7 dai (Fig. 1D). Interestingly, the Ac11 isolate titer was relatively high although disease severity caused by the isolate was low. Surprisingly, about $10^{4} \mathrm{cfu} / \mathrm{g}$ of Ac2 isolate was detected at both 7 and 10 dai (Fig. 1D), indicating that Ac2 can be transmitted through soil and propagate inside the seedlings without symptom development. Overall $\mathrm{Ac0}$, Ac4, and Ac8 were highly virulent in watermelon regardless of $\mathrm{CC}$ group, and Ac2 was almost non-pathogenic. These results indicate that $A$. citrulli can infect watermelon seeds during
A

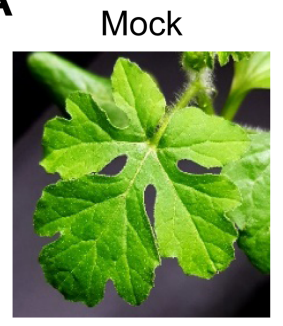

Ac4

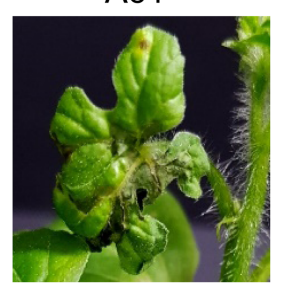

Ac0

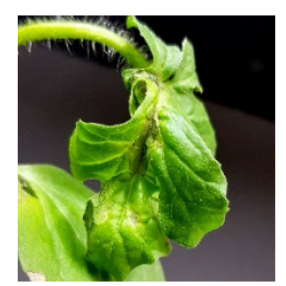

Ac8

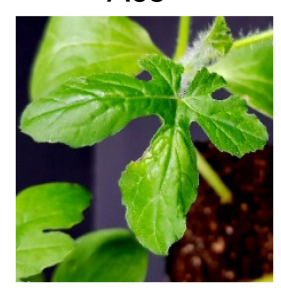

Ac1

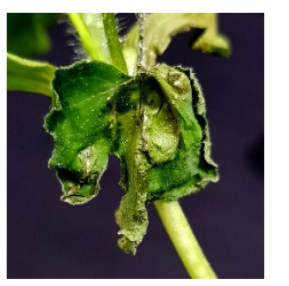

Ac11

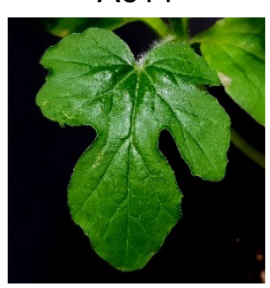

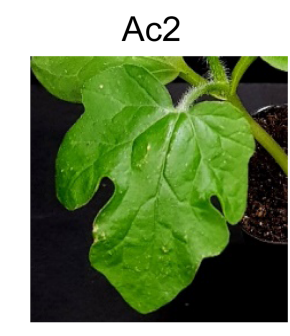

B
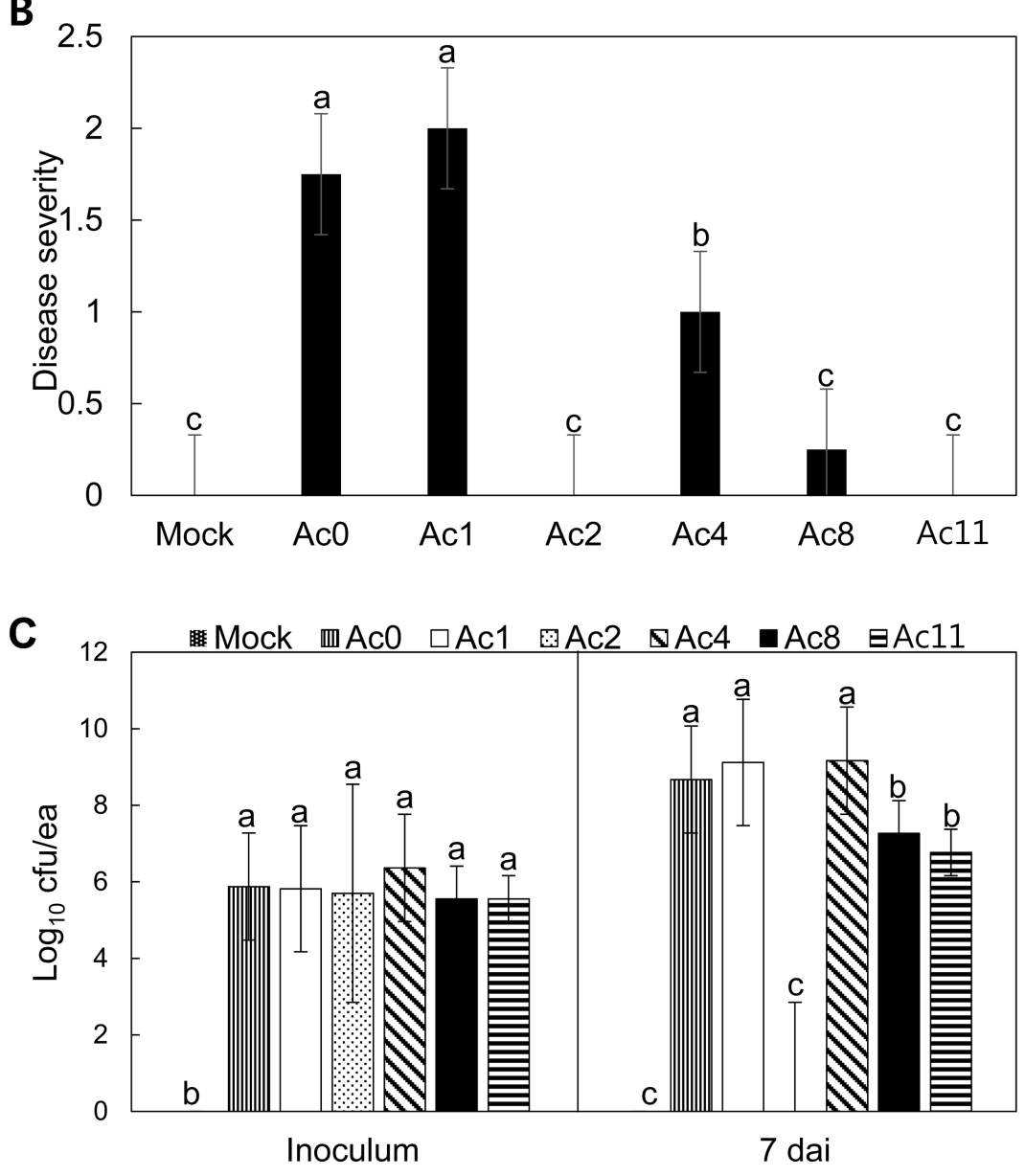

Fig. 3. Infection efficiency and virulence of Acidovorax citrulli isolates infected by spraying on watermelon seedlings. Three-week-old seedlings were sprayed with bacterial suspension $\left(10^{6} \mathrm{cfu} / \mathrm{ml}+0.02 \%\right.$ silwet $)$. Two hours after spraying, seedlings were covered with transparent plastic bags to keep moist inside for 24 h. (A) Symptoms on leaves 7 days after inoculation (dai). (B) The disease severity at 7 dai that was scored according to disease index scale in Supplementary Fig. 1B ( $n$ =4). (C) Measurement of bacterial titers in aerial part of watermelon seedlings at 7 dai. Y-axis indicates the average of bacterial cell numbers per aerial part of each seedling $\left(\log _{10} \mathrm{cfu} / \mathrm{ea}\right)$. Bars represent standard error $(n=4)$ and the letters on top of error bars show results from Duncan's multiple range test $(P<$ 0.05). 
germination in soil and CC grouping is not correlated with the level of virulence in the given condition.

Infection efficiency and virulence of $A$. citrulli isolates through roots. To determine if $A$. citrulli isolates can infect watermelon seedlings through seedling roots, 5-day-old watermelon seedlings with or without wounded roots were inoculated with $A$. citrulli isolates by soil drenching with a $10^{6} \mathrm{cfu} / \mathrm{ml}$ bacterial suspension. Then, disease severity and bacterial titers were measured. Disease symptoms appeared in the wounded seedlings at only 2 dai, but symptoms were not observed in the non-cut roots (Fig. 2A). Interestingly, only $\mathrm{Ac} 0$ and Ac4 isolates, which belong to $\mathrm{CC}$ group II, caused severe disease symptoms (Fig. 2B). A. citrulli infection in seedlings without wounding in roots was poor, with bacterial titers of all $A$. citrulli isolates lower than $10^{3} \mathrm{cfu}$ per root (Fig. 2C). However, infection efficiency dramatically increased through root cutting before inoculation, with bacterial titers detecting up to $10^{8}$ cfu per root for $A$. citrulli isolates Ac0 and Ac4 (Fig. 2C). Although Ac4 and Ac8 isolates did not caused disease symptoms, bacterial population of the two isolates were relatively high (Fig.

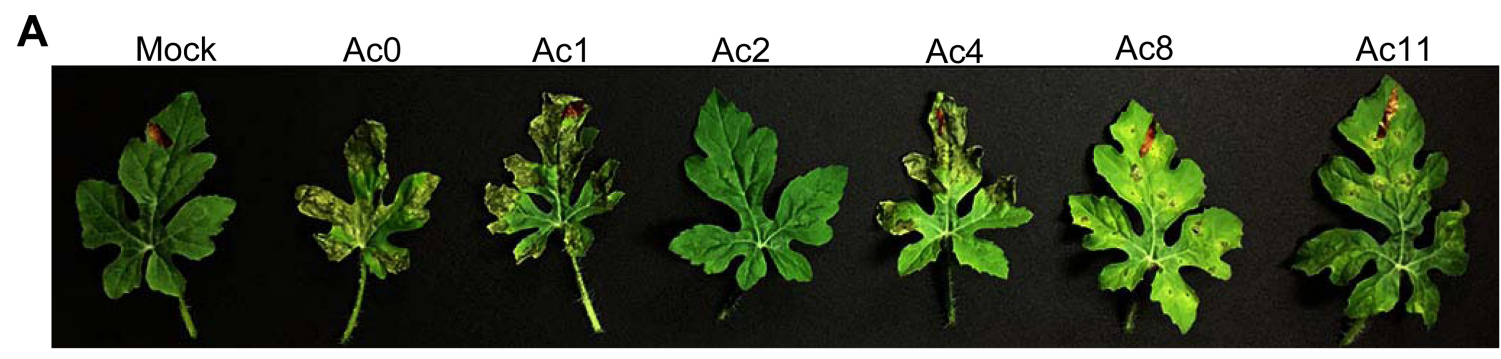

B

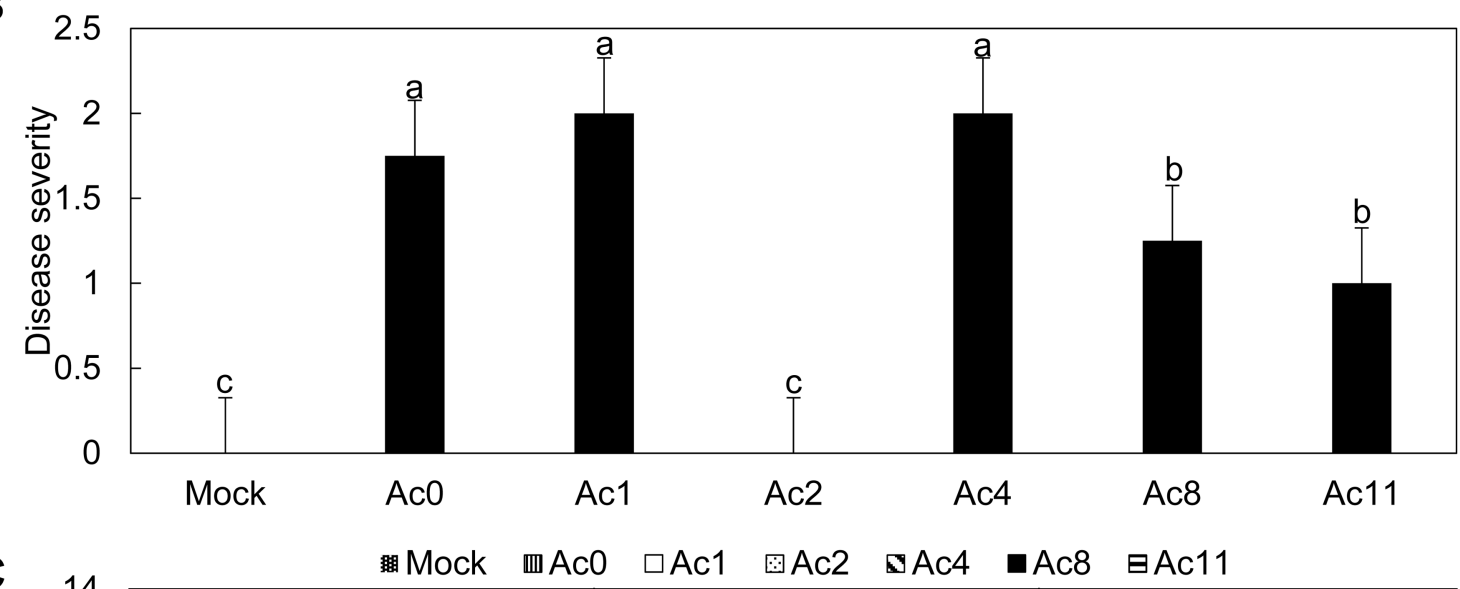

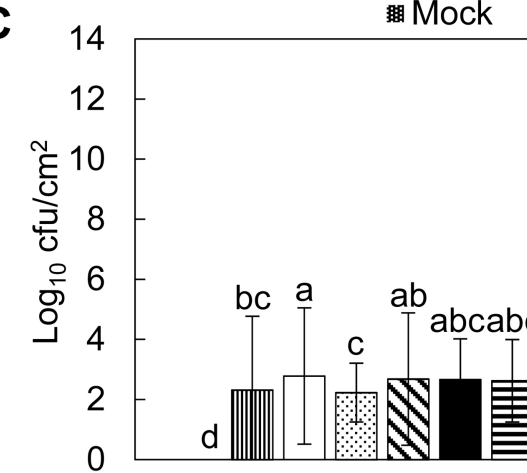

0

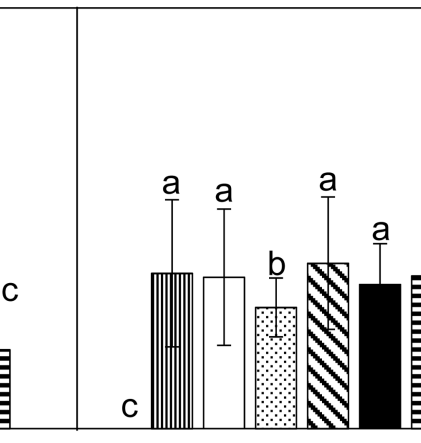

2

Days after infiltration

Fig. 4. Virulence of Acidovorax citrulli isolates infected by syringe infiltration into leaves of 3-week-old watermelon and melon plants. (A) Symptoms in watermelon leaves after infiltration with $10^{4} \mathrm{cfu} / \mathrm{ml}$ of each indicated isolate at 6 days after inoculation (dai). (B) The disease severity at 6 dai that was scored according to disease index scale in Supplementary Fig. 1B $(n=4)$. (C) Bacterial growth in the watermelon leaves. Y-axis indicates the average of $\log _{10} \mathrm{cfu} / \mathrm{cm}^{2}$ in the infected watermelon leaves. Bars represent the standard error $(n=9$; 9 leaf discs/treatment) and the letters on top of error bars show results from Duncan's multiple range test $(P<0.05)$. 
2C). These results indicate that it is difficult for $A$. citrulli to infect watermelon seedlings through intact roots after germination, but wounding can help A. citrulli infect roots.

Infection efficiency and virulence of $A$. citrulli isolates through the leaf surface. One symptom caused by $A$. citrulli is water-soaking in leaves, followed by necrosis. Therefore, the infection efficiency of $A$. citrulli isolates through the leaf surface was determined by the spray inoculation method. Three-week-old watermelon plants were sprayed with $10^{6} \mathrm{cfu} / \mathrm{ml}$ of each A. citrulli isolate. In this case, $0.02 \%$ silwet was added to the bacterial suspension, and plants were covered by transparent plastic bags to hold humidity for $24 \mathrm{~h}$ after spraying. Necrotic disease symptoms in leaves inoculated with $\mathrm{Ac} 0, \mathrm{Ac} 1$, or Ac4 isolates, which belong to $\mathrm{CC}$ group II, were obvious at 7 dai (Fig. 3A). Among these three, Ac1 caused the most severe symptoms (Fig. 3B). However, Ac2, Ac8, and Ac11 iso-

A

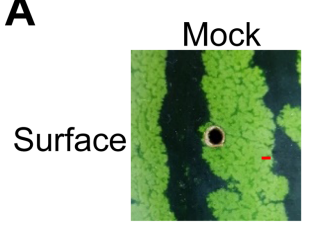

$\mathrm{Ac0}$

Ac1
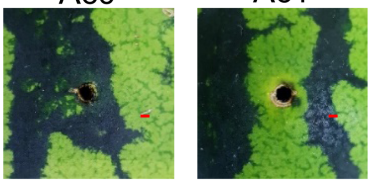

Ac2

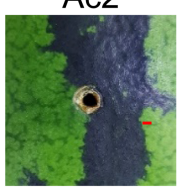

Ac4
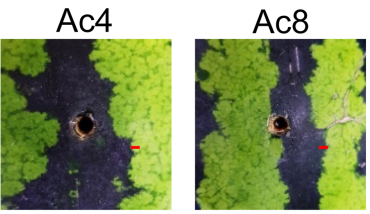

Ac11
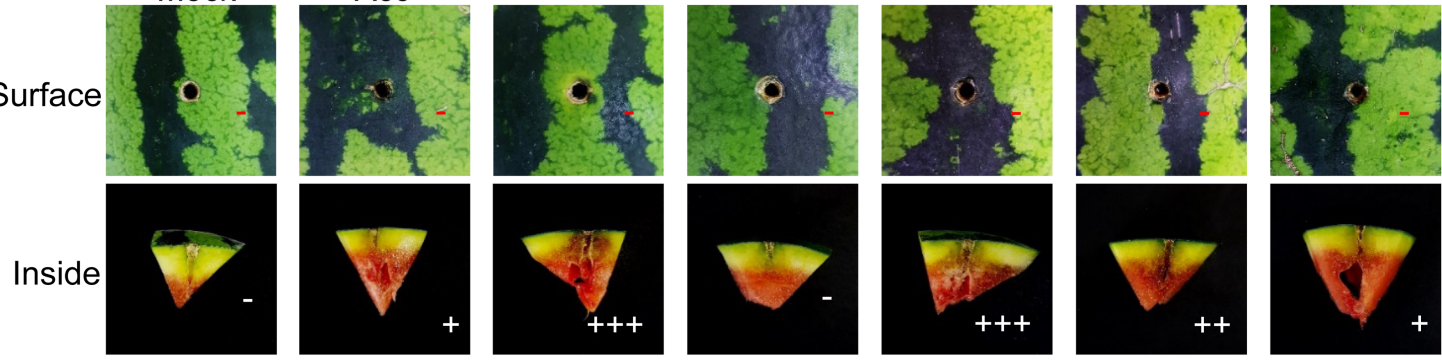

B

Colonies isolated from infected sites

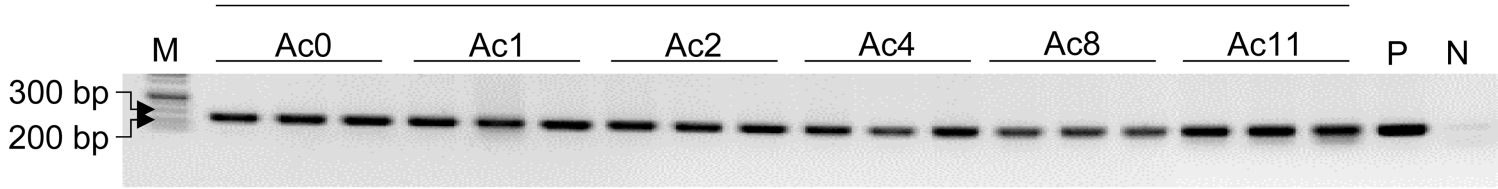

C

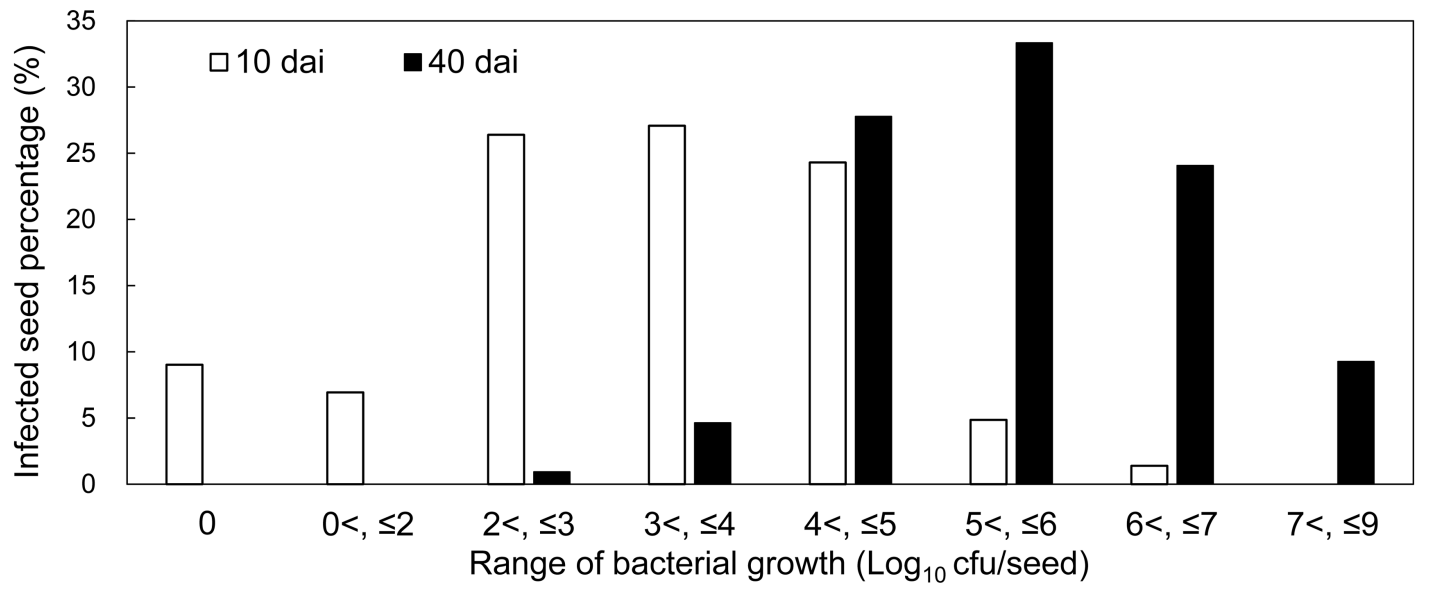

Fig. 5. Virulence of Acidovorax citrulli isolates after inoculation into fully ripe watermelon fruits. Watermelon fruits were inoculated with $10^{6} \mathrm{cfu} / \mathrm{ml}$ of $A$. citrulli isolates using a pipette at a depth of $0.5 \mathrm{~cm}$ from the surface and incubated at room temperature for 40 days. (A) Symptoms in the surface of or inside the watermelon fruits at 24 days after inoculation (dai) with $10^{6} \mathrm{cfu} / \mathrm{ml}$ of each indicated isolate. The mark at the bottom right represents the extent of disease. (B) Confirmation of the presence of inoculated bacteria by PCR using a $16 / 25 \mathrm{~S}$ rRNA gene primer set. The fruit extract was cultured on medium for $24 \mathrm{~h}$ at $26^{\circ} \mathrm{C}$, and colonies on medium were used for PCR. M, 1 kb ladder marker; $\mathrm{P}, \mathrm{Ac} 0$ genomic DNA (positive control); $\mathrm{N}, \mathrm{H}_{2} \mathrm{O}$ (negative control). (C) Percentage of infected seeds collected from watermelons inoculated with Acl isolate $\left(10^{6} \mathrm{cfu} / \mathrm{ml}\right)$. All seeds were collected at 10 dai and 40 dai, and bacterial titers inside each seed were counted. The percentage of seeds with each range of bacterial titer was calculated by the following equation: (number of seeds with each range of bacterial titer/total seed number) $\times 100$. 
lates, which belong to $\mathrm{CC}$ group I, did not show symptoms at the same time point (Fig. 3B). Bacterial titers of Ac0, $\mathrm{Ac} 1$, and Ac4 isolates were $10^{9} \mathrm{cfu}$ per aerial part of each seedling (cfu/ea) (Fig. 3C). Although bacterial titers of Ac8 and Ac11 reached around $10^{7} \mathrm{cfu} / \mathrm{ea}, \mathrm{Ac} 2$ was not detected (Fig. 3C). These results indicate that $A$. citrulli isolates belonging to $\mathrm{CC}$ group II can efficiently infect leaves and cause necrotic symptoms in leaves, but the infection efficiency of isolates belonging to $\mathrm{CC}$ group I is poor.

Virulence of $A$. citrulli isolates infiltrated into watermelon leaves. To bypass the entry step through leaves, $10^{4}$ $\mathrm{cfu} / \mathrm{ml}$ of each $A$. citrulli isolate was infiltrated directly into leaves of 3-week-old watermelon plants using a needleless syringe. Similar to the results from spray inoculation, Ac0, Ac1, and Ac4 isolates caused severe necrosis (Fig. 4A). Bacterial titers of these isolates reached more than $10^{10} \mathrm{cfu}$ per $\mathrm{cm}^{2}$ of inoculated leaves $\left(\mathrm{cfu} / \mathrm{cm}^{2}\right)$ at 4 dai (Fig. $4 \mathrm{C}$ ). However, Ac8 and Ac11, which did not cause any disease symptom with spray inoculation, caused mostly yellowing in the inoculated regions, while Ac2 did not consistently cause disease symptom (Fig. 4B). Bacterial titers of Ac8 and Ac11 reached $10^{7} \mathrm{cfu} / \mathrm{cm}^{2}$, which was similar to the level by spray inoculation at four dai (Fig. 4C). Unlike with the spray inoculation method, Ac2 multiplied almost up to $10^{6} \mathrm{cfu} / \mathrm{cm}^{2}$ at 4 dai, indicating that, although the entry from the leaf surface was poor, Ac2 had the ability to grow inside the leaf tissue. In addition to syringe infiltration, vacuum infiltration of the whole plants with $10^{4} \mathrm{cfu} / \mathrm{ml}$ of the same Ac isolates with $0.02 \%$ silwet was performed. Overall results were very similar to those of syringe infiltration, although disease symptom development was weaker and bacterial titers were lower (Supplementary Fig. 2).

Virulence of $A$. citrulli isolates in mature watermelon fruits and their infectivity to seeds. The most typical symptom caused by $A$. citrulli in watermelon is fruit blotch. To determine virulence of $A$. citrulli isolates in mature watermelon fruits, $10^{6} \mathrm{cfu} / \mathrm{ml}$ of each isolate was inoculated using a pipette at a depth of $0.5 \mathrm{~cm}$ from the surface, and symptom development in fruits and infectivity to seeds inside were monitored for 40 days after inoculation. Blotch symptoms were developed inside the inoculation sites, although symptoms were not obvious outside the fruits. Among the six isolates, Ac1 and Ac4 caused severe blotch symptoms inside, Ac0, Ac8, and Ac11 caused little, and Ac2 did not cause (Fig. 5A). Inoculation made at a lower depth showed the same results (data not shown). The presence of inoculated Ac isolates at sites showing symptoms was confirmed by PCR with an A. citrulli-specific primer set after isolating bacteria from a fruit extract (Fig. 5B). Finally, infectivity of $A$. citrulli isolates to seeds was determined only with the Ac1 isolate, which caused severe symptom in fruits. A total of 144 and 108 seeds were collected from the inoculated watermelons at 10 dai and 40 dai respectively, and bacterial titers were measured. At 10 dai, only approximately $9 \%$ of seeds (13 out of 144 seeds) were pathogen-free and seeds carrying $10^{2}$ to $10^{4} \mathrm{cfu} / \mathrm{seed}$ were dominant, while at 40 dai, all seeds were infected with more than $10^{2} \mathrm{cfu} / \mathrm{seed}$ and seeds carrying $10^{5}$ to $10^{7}$ $\mathrm{cfu} /$ seed were dominant (Fig. 5C), indicating that Ac1 infects seeds very efficiently and more bacteria colonize inside seeds as time goes on.

Profiles of putative effector genes of $A$. citrulli isolates. Sixteen putative effector genes were found in the genome of $A$. citrulli strain AAC00-1 from previous reports (Bahar and Burdman, 2010; Eckshtain-Levi et al., 2014) and genome searching with Artemis v.17.0.1. Profiles of those effector genes were determined in Ac0 isolate, using the genome sequence (Park et al., 2017) and PCR with gene-specific primers and DNA sequencing for other five isolates (Table 2). Ac0, Ac1, and Ac4 isolates carried all genes, while Ac2, Ac8 and Ac11 isolates carried only thirteen intact genes. The latter three isolates carried two nonfunctional effector genes, Aave_2166 and Aave_3062, which encode homologs of AvrBsT and AvrRxol of $X$. euvesicatoria, respectively, due to deletion of certain bases or transposon insertion, resulting in early translational stop. Moreover, these isolates lacked the Aave_2708 gene, which encodes the XopJ homolog of $X$. euvesicatoria. Because only Ac0, Ac1 and Ac4 among the six isolates showed high virulence through leaves, these three putative effector genes (Aave_2166, Aave_2708, and Aave_3062) may be important for leaf infection or $\mathrm{CC}$ grouping.

\section{Discussion}

In this study, we showed that $A$. citrulli could infect watermelon through diverse routes, including seeds during germination, roots, leaves, and fruits, which are equivalent to sites where disease symptoms develop under the natural conditions (Latin and Hopkins, 1995). However, this statement appears correct only when many $A$. citrulli isolates are considered as a single population because not all isolates can infect through all possible routes. Out study showed that the infection routes of certain $A$. citrulli isolates might be limited because three out of six A. citrulli isolates were virulent only when they contacted certain organs (Table 3 ). This indicates that virulence of $A$. citrulli 
Table 2. Profiles of putative effector genes in six Ac isolates confirmed by PCR with gene-specific primers and DNA sequencing

\begin{tabular}{|c|c|c|c|c|c|c|c|c|c|}
\hline \multirow{2}{*}{$\begin{array}{l}\text { Putative } \\
\text { effector gene }\end{array}$} & \multirow{2}{*}{ Protein homolog ${ }^{\mathrm{b}}$} & \multirow{2}{*}{$\begin{array}{l}\text { Identity } \\
(\%)^{\mathrm{b}}\end{array}$} & \multirow{2}{*}{$\begin{array}{l}\text { Positives } \\
(\%)^{\mathrm{b}}\end{array}$} & \multicolumn{6}{|c|}{ Acidovorax citrulli isolates } \\
\hline & & & & Ac0 & Ac1 & Ac2 & Ac4 & Ac8 & Ac11 \\
\hline Aave_0277 & HopG1 of Ralstonia solanacearum & 65 & 78 & + & + & + & + & + & + \\
\hline Aave_1373 & AvrXv3 of Xanthomonas euvesicatoria & 50 & 62 & + & + & + & + & + & + \\
\hline Aave_1548 & $\begin{array}{l}\text { HopW1-1 (HopPmaA) of Pseudomonas syringae pv. } \\
\text { maculicola }\end{array}$ & 53 & 70 & + & + & + & + & + & + \\
\hline Aave_2166 & AvrBsT of $X$. euvesicatoria & 66 & 81 & + & + & $\operatorname{Del}^{\mathrm{c}}$ & + & $\operatorname{Del}^{\mathrm{c}}$ & $\operatorname{Del}^{\mathrm{c}}$ \\
\hline Aave_2173 & AvrBs1 of Xanthomonas gardneri & 45 & 63 & + & + & + & + & + & + \\
\hline $\begin{array}{l}\text { Aave_2708 } \\
\text { (Aave_2938) }\end{array}$ & XopJ of $X$. euvesicatoria & 100 & 100 & + & + & - & + & - & - \\
\hline Aave_2801 & Rsc 0782 of $R$. solanacearum & 46 & 57 & + & + & + & + & + & + \\
\hline Aave_2802 & HopD1 of $P$. syringae pv. tomato & 26 & 41 & + & + & + & + & + & + \\
\hline Aave_2876 & HopH1 of $P$. syringae & 42 & 62 & + & + & + & + & + & + \\
\hline Aave_3051 & HopF2 of $P$. syringae pv. antirrhini & 37 & 65 & + & + & + & + & + & + \\
\hline Aave_3062 & AvrRxo1 of $X$. translucens & 71 & 81 & + & + & $\operatorname{In}^{\mathrm{d}}$ & + & $\operatorname{Del}^{\mathrm{e}}$ & $\operatorname{Del}^{\mathrm{e}}$ \\
\hline Aave_3237 & Lytic murein transglycosylase of $A$. citrulli & 100 & 100 & + & + & + & + & + & + \\
\hline Aave_3452 & AvrPphE of $R$. solanacearum & 44 & 57 & + & + & + & + & + & + \\
\hline Aave_3462 & PopP3 (YopJ family) of $R$. solanacearum & 35 & 50 & + & + & + & + & + & + \\
\hline Aave_3502 & HopAO1 (HopD2) of P. syringae & 48 & 63 & + & + & + & + & + & + \\
\hline Aave_4606 & RipAY of $R$. solanacearum & 42 & 58 & + & + & + & + & + & + \\
\hline Aave_4728 & RipBI protein of $R$. solanacearum & 33 & 47 & + & + & + & + & + & + \\
\hline
\end{tabular}

+ , Presence of indicated genes; -, absence of indicated genes.

a Obtained from Eckshtain-Levi et al. (2014), Fujiwara et al. (2016), Lo et al. (2017), Potnis et al. (2012), and Washington et al. (2016).

${ }^{\mathrm{b}}$ Protein homologs and amino acid identity and positives by BLASTP at GenBank database.

cDeletion of $120 \mathrm{bp}$ including a start codon causing no intact proteins.

dInsertion of a 876-bp transposase within an ORF causing early termination.

${ }^{\mathrm{e}}$ Deletion of one base within an ORF causing frame shift and early termination.

isolates might be different depending on where they first contact a host plant. Only two among six $A$. citrulli isolates could efficiently infect watermelon through all infection routes tested, although its virulence level varied (Table 3 ). The virulence in an organ-specific manner might be one of characteristics of $A$. citrulli causing BFB in watermelon.

Plant-pathogenic bacteria, which mostly have semibiotrophic lifestyle, seem to have preferred organs for infection such as roots and leaves. Depending on the infection routes, disease symptoms are normally developed at the initial infection organ, at distal organs, or in the entire plants (Bové and Garnier, 2002). If pathogens infect leaves of host plants like Pseudomonas syringae pv. tomato and $X$. euvesicatoria in tomato (Boureau et al., 2002; Potnis et al., 2015), then they normally cause spot-type symptoms at the infection sites. However, if pathogens infect vascular systems or roots, like Ralstonia solanacearum in tomato, $X$. oryzae pv. oryzae in rice, and Erwinia amylovora in apple and pear (Mew et al., 1993; Tans-Kersten et al., 2001; Vanneste, 2000), they cause wilting or blight-type symptoms in the entire plants or twigs. Some of plant-pathogenic bac- teria can cause disease symptoms in multiple organs of the host plants. $P$. syringae pv. tomato and $X$. euvesicatoria in tomato cause disease symptoms not only in leaves, but also in fruits. More obviously, $P$. syringae pv. actinidiae, the pathogen that causes bacterial canker in kiwifruit, can cause disease symptoms in leaves, flowers, and stems (Scortichini et al., 2012). However, the knowledge about organ-specific virulence of each plant-pathogenic bacterium is limited, except in pathogens mainly infecting leaves. Therefore, it would be worthy to determine the genes controlling virulence in an organ-specific manner and eventually discover the underlying molecular mechanisms.

A. citrulli isolates having different infectivity in diverse routes in watermelon may be good materials to study this subject, because profiles of effector genes are positively correlated with infectivity in an organ-specific manner, as summarized in Tables 2 and 3. Generally, effector genes encoding proteins delivered into host plant cells are virulence determinants in plant-pathogenic bacteria (Alfano and Collmer, 2004; Bogdanove et al., 1996). Combinations of effector genes in a single pathogenic bacterium control 
Table 3. Summary of disease severity by Acidovorax citrulli isolates in watermelon depending on inoculation methods and sites

\begin{tabular}{|c|c|c|c|c|c|c|c|}
\hline \multirow{2}{*}{$\begin{array}{l}\begin{array}{l}\text { Inoculation } \\
\text { method }\end{array} \\
\text { Plant stages }\end{array}$} & \multirow{2}{*}{$\begin{array}{l}\text { Soil mixing } \\
\text { Mature seeds }\end{array}$} & \multicolumn{2}{|c|}{ Soil drenching } & \multirow{2}{*}{$\begin{array}{c}\text { Spray } \\
\text { inoculation } \\
\text { 3-Week-old } \\
\text { seedlings }\end{array}$} & \multirow{2}{*}{$\begin{array}{c}\begin{array}{c}\text { Syringe } \\
\text { infiltration }\end{array} \\
\text { 3-Week-old } \\
\text { seedlings }\end{array}$} & \multirow{2}{*}{$\begin{array}{c}\begin{array}{c}\text { Vacuum } \\
\text { infiltration }\end{array} \\
\text { 3-Week-old } \\
\text { seedlings }\end{array}$} & \multirow{2}{*}{$\begin{array}{l}\text { Fruit injection } \\
\text { Mature fruits }\end{array}$} \\
\hline & & $\begin{array}{l}\text { 5-Day-old } \\
\text { seedlings }\end{array}$ & $\begin{array}{l}\text { 5-Day-old } \\
\text { seedlings }\end{array}$ & & & & \\
\hline Infection sites & $\begin{array}{c}\text { Seeds and } \\
\text { developing roots }\end{array}$ & $\begin{array}{c}\text { Developed } \\
\text { healthy roots }\end{array}$ & $\begin{array}{l}\text { Wounded } \\
\text { roots }\end{array}$ & $\begin{array}{l}\text { Whole } \\
\text { seedlings }\end{array}$ & Leaves & $\begin{array}{l}\text { Whole } \\
\text { seedlings }\end{array}$ & Fruit surface \\
\hline $\begin{array}{l}\text { Inoculum concen- } \\
\text { tration (cfu/ml) }\end{array}$ & $\begin{array}{l}3 \times 10^{5} \\
(\mathrm{cfu} / \mathrm{g})\end{array}$ & $10^{6}$ & $10^{6}$ & $10^{6}$ & $10^{4}$ & $10^{4}$ & $10^{6}$ \\
\hline \multicolumn{8}{|l|}{ Natural isolates } \\
\hline $\mathrm{Ac} 0$ & $++^{*}$ & - & H+ & ++ & +H+ & + & + \\
\hline Ac1 & + & - & - & +++ & +++ & + & +r+ \\
\hline Ac2 & - & - & - & - & - & - & - \\
\hline Ac4 & t+t & - & +H+ & +t+ & ++ & + & +++ \\
\hline Ac8 & +++ & - & - & - & + & - & ++ \\
\hline Ac11 & + & - & - & - & + & - & + \\
\hline
\end{tabular}

${ }^{a}$ Level of disease severity. +++, very severe; ++, severe; +, weak; -, very mild or no disease symptom developed.

its virulence level including infection strategy. The function of three effector genes, Aave_2166, Aave_2708, and Aave_3062, may be critical for infection in leaves because Ac2, Ac8, and Ac11 isolates lacking these functional genes could not cause disease through leaves with the spray inoculation (Tables 2 and 3).

Aave_2166 encodes a homolog to AvrBsT, a gene with acetyltransferases enzyme activity reported from $X$. euvesicatoria (Cheong et al., 2014; Kim et al., 2010). The 39-kDa AvrBsT protein is a member of the YopJ family of effectors in plant and animal pathogens (Ciesiolka et al., 1999; Escolar et al., 2001). AvrBsT is also a well-known host determinant because $X$. euvesicatoria carrying AvrBsT is impossible to cause the disease in pepper, but it can infect tomato (Minsavage et al., 1990). In pepper, AvrBsT suppresses the hypersensitive response induced by another effector protein AvrBs1 of $X$. euvesicatoria (Kim et al., 2010; Szczesny et al., 2010), and this suppression is dependent on SNF1-related kinase, SnRK1, which is located in the plant cell cytoplasm (Szczesny et al., 2010). Interestingly, Aave_2173 in A. citrulli is a homolog of AvrBs1 in $X$. gardneri (Table 2). Thus, it will be worthwhile to determine the relationship between Aave_2166 and Aave_2173 in watermelon. Aave_2708 is a homolog of XopJ, which also belongs to the YopJ family. XopJ inhibits vesicle trafficking and protein secretion to suppress cell wall associated defense responses and degrades the proteasome subunit RPT6 of the host cell to suppress salicylic-acid mediated plant defense (Bartetzko et al., 2009; Üstün and Börnke, 2015; Üstün et al., 2013). Aave_3062 is homologous to AvrRxo1 of $X$. euvesicatoria. The AvrRxo1 locus contains two ORFs: AvrRxo1-ORF1 with a polynucleotide kinase domain and its interactor AvrRxo1-ORF2 (Han et al., 2015). A. citrulli carries the Aave_3063 gene next to Aave_3062, which is homologous to AvrRxo1-ORF2. This suggests that Aave_3062 might function similarly to AvrRxo1. The protein structure of AvrRxo1 is similar to a zeta $(\zeta)$ toxin, which is a part of the toxin-antitoxin system in Streptococcus (Triplett et al., 2016). Moreover, it has recently been revealed that AvrRxo1 phosphorylates NAD in planta and its kinase catalytic sites are necessary for its toxic and resistance-triggering phenotypes (Shidore et al., 2017). Leaves in plants are composed of metabolically active cells including photosynthetic activity compared with cells in roots or fruits (Sonnewald and Fernie, 2018). It can be postulated that the three effectors have functions to interfere with host mechanisms in leaves and to promote diseases. Therefore, they may possess roles to determine infectivity in different organs. Nevertheless, further research should be done to elucidate how these three effector proteins control virulence of $A$. citrulli in an organ-specific manner.

A. citrulli causes disease symptoms in fruits, cotyledons, leaves, and whole plants. This bacterium has been considered a seed-borne pathogen (Burdman and Walcott, 2012), and several works have been done to study other infection routes of this pathogen with diverse natural isolates. When we consider how $A$. citrulli enters seeds initially, it seems that it travels into xylem vessels from an initial infection site (Bahar et al., 2009) and moves to the seeds during development. This means that there are other initial infection sites, and to determine these would be very critical to our 
understanding of the complete disease cycle of $A$. citrulli and eventually for disease management. In this study, we used several inoculation methods and showed that this pathogen can infect host plants through seeds during germination, wounded roots, leaves, and fruits. Our inoculation strategies mimic the conditions or steps that $A$. citrulli may face in watermelon plants from seeds to mature fruits. Moreover, our results show several possible occasions where $A$. citrulli can enter host plants such as the seed germination step in the nursery, the transplanting step in the greenhouse or field, flowering or fruit developing steps, or overhead irrigation.

A. citrulli is normally divided into two CC groups, based on genetic differences (Eckshtain-Levi et al., 2014). However, the correlation between these groups and level of virulence or infection routes in host plants is not clear. In this study, we showed that, among several inoculation methods, the spray inoculation (infection through leaves) could match $\mathrm{CC}$ grouping with virulence in watermelon leaves and the three genes, Aave_2166, Aave_2708, and Aave_3062, with the intact form were found in only CC group II. Other than this, there were no obvious correlations between the two aspects. It remains to be determined that CC grouping might correlate with virulence in host plants that we have not tested, such as melon and cucumber.

\section{Acknowledgments}

We thank Dr. Young-Tak Kim and Dr. Jang-Ha Lee at Nongwoo Bio Co., LTD for providing $A$. citrulli isolates and watermelon seeds, respectively. This work was supported by the research grant from Nongwoo Bio Co., LTD and the National Research Foundation of Korea (NRF) grant funded by the Korean government (MSIT) (No. 2018R1A5A1023599, SRC).

\section{Electronic Supplementary Material}

Supplementary materials are available at The Plant Pathology Journal website (http://www.ppjonline.org/).

\section{References}

Alfano, J. R. and Collmer, A. 2004. Type III secretion system effector proteins: double agents in bacterial disease and plant defense. Annu. Rev. Phytopathol. 42:385-414.

Alves, A. D. O., Xavier, A. D. S., Viana, I. O., Mariano, R. D. L. R. and Silveira, E. B. D. 2010. Colonization dynamics of Acidovorax citrulli in melon. Trop. Plant Pathol. 35:368-372.
Bahar, O. and Burdman, S. 2010. Bacterial fruit blotch: a threat to the cucurbit industry. Isr. J. Plant Sci. 58:19-31.

Bahar, O., Goffer, T. and Burdman, S. 2009. Type IV Pili are required for virulence, twitching motility, and biofilm formation of Acidovorax avenae subsp. citrulli. Mol. Plant-Microbe Interact. 22:909-920.

Bartetzko, V., Sonnewald, S., Vogel, F., Hartner, K., Stadler, R., Hammes, U. Z. and Börnke, F. 2009. The Xanthomonas campestris pv. vesicatoria type III effector protein XopJ inhibits protein secretion: evidence for interference with cell wall-associated defense responses. Mol. Plant-Microbe Interact. 22:655-664.

Block, C. C. and Shepherd, L. M. 2008. Long-term survival and seed transmission of Acidovorax avenae subsp. citrulli in melon and watermelon seed. Plant Health Prog. 9:36.

Bogdanove, A. J., Beer, S. V., Bonas, U., Boucher, C. A., Collmer, A., Coplin, D. L., Cornelis, G. R., Huang, H. C., Hutcheson, S. W., Panopoulos, N. J. and Van Gijsegem, F. 1996. Unified nomenclature for broadly conserved hrp genes of phytopathogenic bacteria. Mol. Microbiol. 20:681-683.

Boureau, T., Routtu, J., Roine, E., Taira, S. and Romantschuk, M. 2002. Localization of hrpA-induced Pseudomonas syringae pv. tomato DC3000 in infected tomato leaves. Mol. Plant Pathol. 3:451-460.

Bové, J. M. and Garnier, M. 2002. Phloem-and xylem-restricted plant pathogenic bacteria. Plant Sci. 163:1083-1098.

Burdman, S. and Walcott, R. 2012. Acidovorax citrulli: generating basic and applied knowledge to tackle a global threat to the cucurbit industry. Mol. Plant Pathol. 13:805-815.

Chalupowicz, L., Dror, O., Reuven, M., Burdman, S. and Manulis-Sasson, S. 2015. Cotyledons are the main source of secondary spread of Acidovorax citrulli in melon nurseries. Plant Pathol. 64:528-536.

Cheong, M. S., Kirik, A., Kim, J.-G., Frame, K., Kirik, V. and Mudgett, M. B. 2014. AvrBsT acetylates Arabidopsis ACIP1, a protein that associates with microtubules and is required for immunity. PLoS Pathog. 10:e1003952.

Choi, O., Park, J.-J. and Kim, J. 2016. Tetranychus urticae (Acari: Tetranychidae) transmits Acidovorax citrulli, causal agent of bacterial fruit blotch of watermelon. Exp. Appl. Acarol. 69:445-451.

Ciesiolka, L. D., Hwin, T., Gearlds, J. D., Minsavage, G. V., Saenz, R., Bravo, M., Handley, V., Conover, S. M., Zhang, H., Caporgno, J., Phengrasamy, N. B., Toms, A. O., Stall, R. E. and Whalen, M. C. 1999. Regulation of expression of avirulence gene $a v r R x v$ and identification of a family of host interaction factors by sequence analysis of avrBsT. Mol. PlantMicrobe Interact. 12:35-44.

Dutta, B., Avci, U., Hahn, M. G. and Walcott, R. R. 2012. Location of Acidovorax citrulli in infested watermelon seeds is influenced by the pathway of bacterial invasion. Phytopathology 102:461-468.

Eckshtain-Levi, N., Munitz, T., Živanović, M., Traore, S. M., Spröer, C., Zhao, B., Welbaum, G., Walcott, R., Sikorski, 
J. and Burdman, S. 2014. Comparative analysis of type III secreted effector genes reflects divergence of Acidovorax citrulli strains into three distinct lineages. Phytopathology 104:1152-1162.

Escolar, L., Van Den Ackerveken, G., Pieplow, S., Rossier, O. and Bonas, U. 2001. Type III secretion and in planta recognition of the Xanthomonas avirulence proteins AvrBs1 and AvrBsT. Mol. Plant Pathol. 2:287-296.

Feng, J., Schuenzel, E. L., Li, J. and Schaad, N. W. 2009. Multilocus sequence typing reveals two evolutionary lineages of Acidovorax avenae subsp. citrulli. Phytopathology 99:913920.

Fujiwara, S., Kawazoe, T., Ohnishi, K., Kitagawa, T., Popa, C., Valls, M., Genin, S., Nakamura, K., Kuramitsu, Y., Tanaka, N. and Tabuchi, M. 2016. RipAY, a plant pathogen effector protein, exhibits robust $\gamma$-glutamyl cyclotransferase activity when stimulated by eukaryotic thioredoxins. J. Biol. Chem. 291:6813-6830.

Han, Q., Zhou, C., Wu, S., Liu, Y., Triplett, L., Miao, J., Tokuhisa, J., Deblais, L., Robinson, H., Leach, J. E. and Zhao, B. 2015. Crystal structure of Xanthomonas AvrRxo1-ORF1, a type III effector with a polynucleotide kinase domain, and its interactor AvrRxo1-ORF2. Structure 23:P1900-P1909.

Hopkins, D. L. and Thompson, C. M. 2002. Seed transmission of Acidovorax avenae subsp. citrulli in cucurbits. HortScience 37:924-926.

Kim, N. H., Choi, H. W. and Hwang, B. K. 2010. Xanthomonas campestris pv. vesicatoria effector AvrBsT induces cell death in pepper, but suppresses defense responses in tomato. Mol. Plant-Microbe Interact. 23:1069-1082.

Kubota, M., Hagiwara, N. and Shirakawa, T. 2012. Disinfection of seeds of cucurbit crops infested with Acidovorax citrulli with dry heat treatment. J. Phytopathol. 160:364-368.

Latin, R. X. and Hopkins, D. L. 1995. Bacterial fruit blotch of watermelon: the hypothetical exam question becomes reality. Plant Dis. 79:761-765.

Lo, T., Koulena, N., Seto, D., Guttman, D. S. and Desveaux, D. 2017. The HopF family of Pseudomonas syringae type III secreted effectors. Mol. Plant Pathol. 18:457-468.

Makizumi, Y., Igarashi, M., Gotoh, K., Murao, K., Yamamoto, M., Udonsri, N., Ochiai, H., Thummabenjapone, P. and Kaku, H. 2011. Genetic diversity and pathogenicity of cucurbitassociated Acidovorax. J. Gen. Plant Pathol. 77:24-32.

Mew, T. W., Alvarez, A. M., Leach, J. E. and Swings, J. 1993. Focus on bacterial blight of rice. Plant Dis. 77:5-12.

Minsavage, G. V., Dahlbeck, D., Whalen, M. C., Kearney, B., Bonas, U., Staskawicz, B. J. and Stall, R. E. 1990. Genefor-gene relationships specifying disease resistance in Xanthomonas campestris pv. vesicatoria - pepper interactions. Mol. Plant-Microbe Interact. 3:41-47.

Neto, E. B. S., Silveira, E. B., Mariano, R. L. R., Nogueira, N. L., Rossi, M. L. and Santos, L. A. 2006. Penetration and colonization of Acidovorax avenae subsp. citrulli in leaves, seeds and fruits of melon type yellow. Fitopatol. Bras. 31:84-88 (in
Portuguese).

Park, H.-J., Seong, H. J., Sul, W. J., Oh, C.-S. and Han, S.-W. 2017. Complete genome sequence of Acidovorax citrulli strain KACC17005, a causal agent for bacterial fruit blotch on watermelon. Korean J. Microbiol. 53:340-341.

Potnis, N., Minsavage, G., Smith, J. K., Hurlbert, J. C., Norman, D., Rodrigues, R., Stall, R. E. and Jones, J. B. 2012. Avirulence proteins AvrBs7 from Xanthomonas gardneri and AvrBs1.1 from Xanthomonas euvesicatoria contribute to a novel gene-for-gene interaction in pepper. Mol. PlantMicrobe Interact. 25:307-320.

Potnis, N., Timilsina, S., Strayer, A., Shantharaj, D., Barak, J. D., Paret, M. L., Vallad, G. E. and Jones, J. B. 2015. Bacterial spot of tomato and pepper: diverse Xanthomonas species with a wide variety of virulence factors posing a worldwide challenge. Mol. Plant Pathol. 16:907-920.

Rahimi-Midani, A., Lee, Y. S., Kang, S.-W., Kim, M.-K. and Choi, T.-J. 2018. First isolation and molecular characterization of bacteriophages infecting Acidovorax citrulli, the causal agent of bacterial fruit blotch. Plant Pathol. J. 34:59-64.

Rane, K. K. and Latin, R. X. 1992. Bacterial fruit blotch of watermelon: association of the pathogen with seed. Plant Dis. 76:509-512.

Schaad, N. W., Postnikova, E. and Randhawa, P. 2003. Emergence of Acidovorax avenae subsp. citrulli as a crop threatening disease of watermelon and melon. In: Pseudomonas syringae and related pathogens: biology and genetic, eds. by $\mathrm{N}$. S. Iacobellis, A. Collmer, S. W. Hutcheson, J. W. Mansfield, C. E. Morris, J. Murillo, N. W. Schaad, D. E. Stead, G. Surico and M. S. Ullrich, pp. 573-581. Kluwer Academic Publishers, Dordrecht, Netherlands.

Schaad, N. W., Postnikova, E., Sechler, A., Claflin, L. E., Vidaver, A. K., Jones, J. B., Agarkova, I., Ignatov, A., Dickstein, E. and Ramundo, B. A. 2008. Reclassification of subspecies of Acidovorax avenae as A. Avenae (Manns 1905) emend., A. cattleyae (Pavarino, 1911) comb. nov., A. citrulli (Schaad et al., 1978) comb. nov., and proposal of A. oryzae sp. nov. Syst. Appl. Microbiol. 31:434-446.

Schaad, N. W., Song, W.-Y. and Hatziloukas, E. 2000. PCR primers for detection of plant pathogenic species and subspecies of Acidovorax. United States Department of Agriculture patents No. 6146834.

Schaad, N. W., Sowell G. Jr., Goth, R. W., Colwell, R. R. and Webb, R. E. 1978. Pseudomonas pseudoalcaligenes subsp. citrulli subsp. nov. Int. J. Syst. Bacteriol. 28:117-125.

Scortichini, M., Marcelletti, S., Ferrante, P., Petriccione, M. and Firrao, G. 2012. Pseudomonas syringae pv. actinidiae: a reemerging, multi-faceted, pandemic pathogen. Mol. Plant Pathol. 13:631-640.

Shidore, T., Broeckling, C. D., Kirkwood, J. S., Long, J. J., Miao, J., Zhao, B., Leach, J. E. and Triplett, L. R. 2017. The effector AvrRxo1 phosphorylates NAD in planta. PLoS Pathog. 13:e1006442.

Song, J. Y., Park, S. Y., Seo, M. W., Nam, M. H., Lim, H. S., Lee, 
S.-C., Lee, Y. S. and Kim, H. G. 2015. Genetic characteristics of Acidovorax citrulli population causing bacterial fruit blotch against cucurbits in Korea. Res. Plant Dis. 21:82-88 (in Korean).

Sonnewald, U. and Fernie, A. R. 2018. Next-generation strategies for understanding and influencing source-sink relations in crop plants. Curr. Opin. Plant Biol. 43:63-70.

Szczesny, R., Büttner, D., Escolar, L., Schulze, S., Seiferth, A. and Bonas, U. 2010. Suppression of the AvrBs1-specific hypersensitive response by the YopJ effector homolog AvrBsT from Xanthomonas depends on a SNF1-related kinase. New Phytol. 187:1058-1074.

Tans-Kersten, J., Huang, H. and Allen, C. 2001. Ralstonia solanacearum needs motility for invasive virulence on tomato. $J$. Bacteriol. 183:3597-3605.

Triplett, L. R., Shidore, T., Long, J., Miao, J., Wu, S., Han, Q., Zhou, C., Ishihara, H., Li, J., Zhao, B. and Leach, J. E. 2016. AvrRxo1 is a bifunctional type III secreted effector and toxinantitoxin system component with homologs in diverse environmental contexts. PLoS ONE 11:e0158856.

Üstün, S., Bartetzko, V. and Börnke, F. 2013. The Xanthomonas campestris type III effector XopJ targets the host cell proteasome to suppress salicylic-acid mediated plant defence. PLoS Pathog. 9:e1003427.

Üstün, S. and Börnke, F. 2015. The Xanthomonas campestris type III effector XopJ proteolytically degrades proteasome subunit RPT6. Plant Physiol. 168:107-119.
Vanneste, J. L. 2000. Fire blight: the disease and its causative agent, Erwinia amylovora. CABI Publishing, Wallingford, UK. 370 pp.

Walcott, R. R., Fessehaie, A. and Castro, A. 2004. Differences in pathogenicity between two genetically distinct groups of Acidovorax avenae subsp. citrulli on cucurbit hosts. J. Phytopathol. 152:277-285.

Walcott, R. R., Gitaitis, R. D. and Castro, A. C. 2003. Role of blossoms in watermelon seed infestation by Acidovorax avenae subsp. citrulli. Phytopathology 93:528-534.

Washington, E. J., Mukhtar, M. S., Finkel, O. M., Wan, L., Banfield, M. J., Kieber, J. J. and Dangl, J. L. 2016. Pseudomonas syringae type III effector HopAF1 suppresses plant immunity by targeting methionine recycling to block ethylene induction. Proc. Natl. Acad. Sci. U. S. A. 113:E3577-E3586.

Webb, R. E. and Goth, R. W. 1965. A seedborne bacterium isolated from watermelon. Plant Dis. Rep. 49:818-821.

Willems, A., Goor, M., Thielemans, S., Gillis, M., Kersters, K. and De Ley, J. 1992. Transfer of several phytopathogenic Pseudomonas species to Acidovorax as Acidovorax avenae subsp. avenae subsp. nov., comb. nov., Acidovorax avenae subsp. citrulli, Acidovorax avenae subsp. cattleyae, and Acidovorax konjaci. Int. J. Syst. Bacteriol. 42:107-119.

Yan, S., Yang, Y., Wang, T., Zhao, T. and Schaad, N. W. 2013. Genetic diversity analysis of Acidovorax citrulli in China. Eur. J. Plant Pathol. 136:171-181. 